Ireneusz Milewski (Gdańsk)

\title{
A Few Remarks on the Ransom Paid for Releasing Captives in Selected Early Byzantine Hagiographic TeXts ${ }^{*}$
}

B rigandage in all its forms existed and developed throughout antiquity, including Bin the Roman world. To a large extent, it was a symptom of the state's weakness and the various sorts of problems it suffered from. This applied especially to frontier areas, many of which had never been civilized enough: they had not yielded to Romanization (as, for instance, the territories inhabited by the Isaurians ${ }^{1}$ ), nor had they been included under efficient administration within the borders of previous kingdoms. Another problem arises with the decline of antiquity in the West, where, after the year $410 \mathrm{AD}$, the Roman state functioned capably only in Italy. In the other provinces, engulfed by chaos and taken over by barbarians, brigandage and piracy spread freely; it was also practiced by barbarian invaders, particularly by Visigoths and Vandals in the western parts of the Mediterranean Sea ${ }^{2}$. Without delving into the broader context of issues related to brigandage, the following study will present records of several instances focusing on the monetary transactions involved: that is, the ransom paid for releasing captives.

\section{Melania the Younger and piracy in the Mediterranean Sea}

The first of the reports under analysis stems from Gerontius of Jerusalem, who describes Melania the Younger's journey from Italy to Africa. Having just sold a considerable part of her estates in Italy, she heads south to reach Palestine through Africa, Cyrenaica, and Egypt. Although the notion of religious reasons behind her desire to visit Egyptian monks may be maintained - since they were swarmed by

\footnotetext{
" This article was written with the financial support of the Polish National Science Centre (UMO2015/17/B/HS3/00135).

${ }^{1}$ K. Tomaschitz, Unpublizierte Inschriften Westkilikiens aus dem Nachlass Terence B. Mittfords, Wien 1998, p. 35sqq; K. FelD, Barbarische Bürger. Die Isaurier und das Römische Reich, Berlin-New York 2005, p. 102sqq, 183sqq, 194sqq.

${ }^{2}$ Ph. DE Souza, Piracy in the Graeco-Roman World, Cambridge 2002, p. 225.
} 
hysterically pious Roman matrons such as Melania - her stay in Africa Proconsularis was due to purely economic causes ${ }^{3}$. Melania sought to liquidate some of her estates there and to transfer the acquired resources to Palestine in order to cover the costs of the enterprises she planned there. On her way to Africa, she stayed for a while in Sicily, where she also sold her estates (a fact left unmentioned by Gerontius). At this point, for unknown reasons, Melania decided not to continue her journey towards Africa; instead, she turned back to Campania, to her cousin Paulinus, bishop of Nola. On the way there, due to inclement weather, her ship landed on an island (not mentioned by name) which had just been ravaged by pirates. A large part of the inhabitants of the island had been abducted ${ }^{4}$. The pirates (referred to

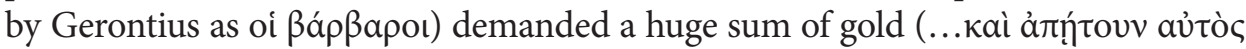

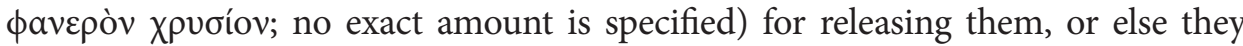
threatened to murder the hostages and pillage the town once again ${ }^{5}$. The latter statement should rather be taken a sign of literary exaggeration. Captives were "merchandise" too valuable to be slaughtered; those who would not be ransomed would be taken to slave markets. Whether in antiquity or in other periods, it was piracy, along with wars of conquest, that constituted the main source of slavery ${ }^{6}$.

The bishop mentioned in Gerontius's report, only able to raise a small part of the demanded sum, asked Melania and Pinianus for help. The couple shelled

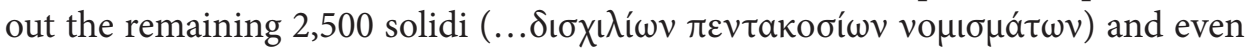
ransomed a certain elderly noble woman from the hands of the pirates. It appears from Gerontius's account that she was the victim of another raid and none of her relatives had helped her; 500 solidi were demanded for her release $e^{7}$. Melania gave

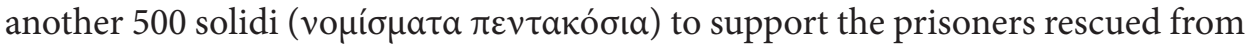

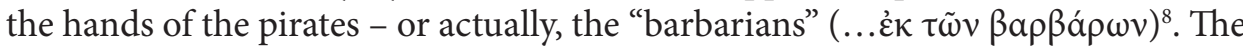
historical accuracy of the event described by Gerontius is challenging to evaluate. The only islands on the route from Sicily to Campania are the Aeolian Islands, an area tormented by piracy throughout antiquity. Needless to say, the islands were not alone in that respect, as the shores of all Italy were raided by sea brigands. The apogee of the attacks occurred in the period from the beginning of the $5^{\text {th }}$ century

\footnotetext{
${ }^{3}$ Cf. also: L.L. Coon, "Through the Eye of a Needle". Wealth and Poverty in the Lives of Helena, Paula, and Melania the Younger, [in:] EADEM, Sacred Fictions. Holy Women and Hagiography in Late Antiquity, Philadelphia 1997, p. 95sqq.

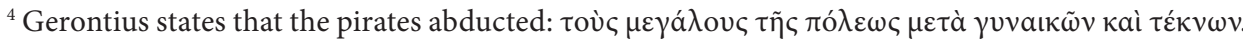
Gerontius, Vita Melaniae iunioris, 19, 168, ed. D. Gorce, Paris 1962 [= SC, 90].

${ }^{5}$ Gerontius, Vita Melaniae iunioris, 19, 168.

${ }^{6}$ L. Schumacher, Sklaverei in der Antike. Alltag und Schicksal der Unfreien, München 2001, p. 34 sqq.

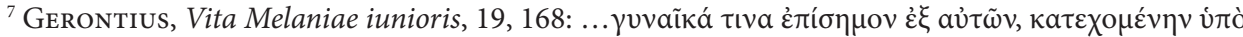

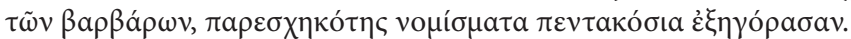

${ }^{8}$ Gerontius, Vita Melaniae iunioris, 19, 168.

${ }^{9}$ Ph. WARD, The Aeolian Islands, New York 1974, p. 7.
} 
(Maximus of Turin describes pirate attacks on the Ligurian Sea and the invasions of Gundobad, king of Burgundians ${ }^{10}$ ) up to the early $7^{\text {th }}$ century ${ }^{11}$.

It is unclear whether the instance of piracy related by Gerontius could be ascribed to the Vandals, who only arrived in the vicinity of Sicily later. Rather, the account either reflects a case of piracy committed by neighbors from nearby islands or it is a mere topical story, of which there are many in hagiographic texts, especially in the early medieval Latin West ${ }^{12}$. As Gerontius observes, the local communities were decimated by pirate attacks and tried to ransom the captives by their own means. That responsibility, known in Roman law as redemptio captivorum, fell on the local bishop if the community lacked sufficient funds. If he was not able to secure the required sum either, he would request support from third parties ${ }^{13}$. This is exactly what the unnamed bishop did when Melania was asked to contribute the missing amount.

As for the sums of money demanded by the pirates in Gerontius's report, there is no reason to question their validity. Melania had just conducted the sale of her Sicilian estates; besides, she had large amounts of gold acquired from the sale of her Roman assets. Moreover, in the later part of the Vita, Gerontius mentions

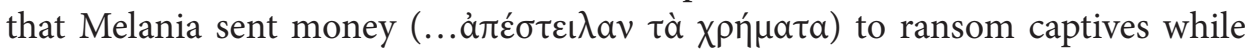
she was in Africa ${ }^{14}$. He does not specify, however, whether in this case we are also dealing with victims of piracy, or whether the events were related to land brigandage or to the Visigoth raids ravaging Italy.

How do the ransom sums mentioned by Gerontius (500 and 2,500 solidi) correlate with analogical data known from other sources? Certain other accounts come to our aid here, e.g. the testimony of Gregory the Great. His letters - an invaluable source for the history of Italy at the turn of the $6^{\text {th }}$ and $7^{\text {th }}$ centuries - provide a considerable amount of information on the topic of the rampant brigandage and recurring barbarian raids plaguing the country. They also sometimes quote exact amounts of ransom paid for releasing captives. Thus, Gregory mentions the sums of 8 solidi (for ransoming a certain Stephanus, otherwise not quite known to

\footnotetext{
${ }^{10}$ A. Merkt, Maximus I. von Turin. Die Verkündigung eines Bischofs der frühen Reichskirche im zeitgeschichtlichen, gesellschaftlichen und liturgischen Kontext, Leiden-New York-Köln 1997, p. 39-47 (the chapter Tumultus bellorum. Turin angesichts der Barbareneinfälle der Jahre 401-412).

${ }^{11}$ Cf. Gregorius Magnus, Epistula, 5, 36, ed. D. Norberg, Turnhout 1982 [= CC.SL, 140]. Cf. also: W. KLINGshirn, Caesarius of Arles and the Ransoming of Captives in Sub-Roman Gaul, JRS 75, 1985, p. 183sqq; H. Grieser, Der Loskauf Gefangener im spätantiken christlichen Italien, [in:] Gefangenenloskauf im Mittelmeerraum. Ein interreligiöser Vergleich. Akten der Tagung von 19. bis 21. September 2013 an der Universität Paderborn, Hildesheim 2015, p. 25sqq.

${ }^{12}$ Cf. F. Graus, Die Gewalt bei den Anfängen des Feudalismus und die "Gefangenbefreiungen" der merowingischen Hagiographie, JWg 1, 1961, p. 61sqq; E. Hermann-Otтo, Der spätantike Bischof zwischen Politik und Kirche. Das exemplarische Wirken von Epiphanius von Pavia, RQ 90, 1995, p. 198sqq.

${ }^{13}$ H. Grieser, Der Loskauf..., p. 28, 35.

${ }^{14}$ Gerontius, Vita Melaniae iunioris, 20, 168.
} 
us) ${ }^{15}, 130$ solidi (for two daughters of a man called Faustinus) ${ }^{16}$ or even 11 pounds of gold (for two clergymen of the bishopric in Fermo), which amounts to a total of almost 800 solidi $^{17}$.

\section{The kidnapped Syrian bishops in the Historia religiosa}

The second of the reports under discussion is found in Theodoret of Cyrus's Historia religiosa and concerns two kidnapped Syrian bishops. Isaurian robbers had threatened northern Syria, as well as the areas of Pontus and eastern Cappadocia, during the entire period of Roman administration ${ }^{18}$, but their raids surged especially in the middle of the $4^{\text {th }}$ century. The circumstances of these most intensified attacks were described by Ammianus Marcellinus. Theodoret relates that the Isaurians rose in rebellion in $353 \mathrm{AD}$, after a certain number of their kinsmen had been caught during a raid and slain in an amphitheater. Isaurian bands assaulted towns on both sides of the Taurus mountains and even mounted a siege of Seleucia ${ }^{19}$. The raiders escalated their incursions in $359 \mathrm{AD}$ and especially in $367 \mathrm{AD}$, when they wreaked havoc in the neighboring Cilicia. As the Roman armies were engaged in operations in the central Danube region, the task of repelling the invaders was entrusted to Musonius, the vicar of the province of Asia; however, he was trapped and defeated by the Isaurians. It was not until Valens sent his legions to the area that the marauders were driven back to their mountain ${ }^{20}$. Zosimos informs us of an Isaurian raid in Lycia and Pamphylia in 375 AD. Yet again, armies sent by emperor Valens from Antioch (where they had been stationed due to a planned expedition against the Persians) pushed the Isaurians back to their mountain dwellings ${ }^{21}$.

In the records from the years 403-408 AD, we learn of yet another threat from the Isaurians. Their activity might have been caused by the doings of Tribigild, a Roman general of Ostrogothic origin who rebelled at the end of the $4^{\text {th }}$ century and ravaged southern Anatolia ${ }^{22}$. According to Philostorgius, the Isaurians revolted once again, this time spreading over the Asia Minor provinces of Caria and Pamphylia, northern Syria, the lands of Armenia Secunda, Syria and Phoenicia ${ }^{23}$,

\footnotetext{
${ }^{15}$ Gregorius Magnus, Epistula 9, 85.

${ }^{16}$ Gregorius Magnus, Epistula, 7, 35.

${ }^{17}$ Gregorius Magnus, Epistula, 9, 52.

${ }^{18}$ K. Feld, Barbarische..., p. 87sqq.

${ }^{19}$ Ammianus Marcellinus, Rerum gestarum libri, XIV, 2, 1-20 (ed. W. Seyfarth, Stuttgart 1996).

${ }^{20}$ Ammianus Marcellinus, Rerum gestarum libri, XXVII, 9, 6-7.

${ }^{21}$ Zosimos, Nova Historia, IV, 20, 1-2 (ed. F. Paschoud, vol. II, Paris 1979).

${ }^{22}$ Zosimos, Nova Historia, V, 14, 5; V, 15, 4-17 (ed. F. Paschoud, vol. III, Paris 1986).

${ }^{23}$ Cf. Sozomenus, Historia ecclesiatica, VIII, 25, ed. J.-P. Migne, Paris 1864 [= PG, 67], col. 1580

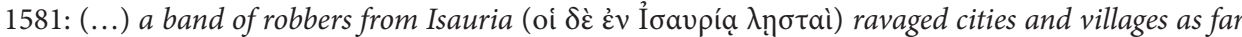
as Caria and Phoenicia. Cf. also: Ammianus Marcellinus, Rerum gestarum libri, XXVIII, 2, 11-14; Socrates, Historia ecclesiastica, II, 33, ed. J.-P. Migne, Paris 1864 [= PG, 67]; Hieronymus, Chronicon, a. 352 (ed. R. Helm, Berlin 1956).
} 
allegedly reaching as far as Cyprus on ships ${ }^{24}$. Isaurian raiding parties even encroached into Palestine, threatening Jerusalem itself ${ }^{25}$.

Towards the end of antiquity, the Isaurians, echoing their previous actions (it will suffice to mention Pompey's attempts to deal with Cilician pirates ${ }^{26}$ ), engaged in maritime brigandage and terrorized the eastern shores of the Mediterranean ${ }^{27}$. Their expeditions had the form of typical raids ${ }^{28}$. It was not until the beginning of the $5^{\text {th }}$ century that the situation was brought more or less under control; but even for that period, reading John Chrysostom's accounts concerning the Isaurian threat, one could get a wholly different impression. Due to the perpetual menace from them, John had his exile destination changed, since it was considered undesirable for a deportee to be taken captive (he would then need to be ransomed back; besides, the political aspects of Chrysostom's exile played a role too). Incidentally, John Chrysostom redeemed captives from the hands of Isaurian robbers as well ${ }^{29}$. Already in the first decade of the $5^{\text {th }}$ century, however, the Isaurians were subdued by Arbazaios, a Roman commander of Armenian or perhaps even Isaurian origin ${ }^{30}$. For the following years, sources cease to mention any raids on a similar scale. It was not until $441 \mathrm{AD}$ that the crisis caused by the Hun invasion led to an Isaurian invasion of Syria once again ${ }^{31}$.

\footnotetext{
${ }^{24}$ Philostorgius, Historia ecclesiastica, XI, 8, ed. J.-P. Migne, Paris 1864 [= PG, 65]; Theodoretus, Historia Religiosa / Histoire des mones de Syrie, X, 5, ed. P. Canivet, A. Leroy-Molinghen, Paris 1977 [= SC, 234].

${ }^{25}$ Palladius, Dialogue sur la vie de Jean Chrysostome, XI, 16, eds A.M. Malingrey, P. LeclercQ, Paris 1988 [= SC, 341-342]; Joannes Chrysostomus, Epistolae ad Olympiadem / Lettres d'exil a Olympias et a tous les fidèles, VI, 1; IX, 2-4; XVI, 1; XVII, 1, ed. A.-M. Malingrey, Paris 1964 [= Sources chrétiennes, 103]. Cf. also: Joannes Chrysostomus, Epistolae, 52, 57, 68, 72, 108, 114, 120, 127, 131, 135, 142, 146, ed. J.-P. Migne, Paris 1862 [= PG, 52]; Hieronymus, Epistulae, 114, 1, ed. J.-P. Migne, Paris 1845 [= PL, 22]: (...) multa in medio (...) praecipue urbs Hierosolymae. Cf. also: K. FeLD, Barbarische..., p. 169-170.

${ }^{26}$ K. Feld, Barbarische..., p. 197sqq.

27 Ammianus Marcellinus, Rerum gestarum libri, XIV, 2, 3 (expedition to Cyprus); Philostorgius, Historia Ecclesiastica, XI, 8 (expedition to Rhodos). Cf. also: K. Feld, Barbarische..., p. 197-200.

${ }^{28}$ K. Feld, Barbarische..., p. 193sqq.

${ }^{29}$ Cf. Sozomenus, Historia ecclesiatica, VIII, 27, col. 1592 - where we read that during his exile,

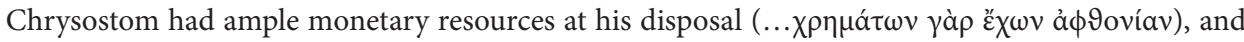
- supplied with money by Olympias and by other supporters - he redeemed numerous captives from

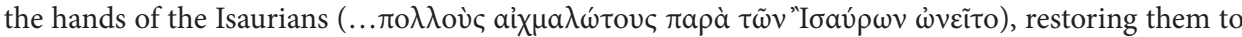

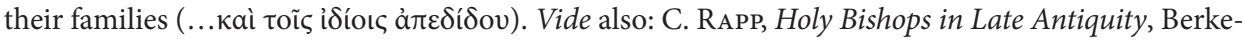
ley 2005, p. 228-232.

${ }^{30}$ K. Feld, Barbarische..., p. 171-192.

${ }^{31}$ Marcellinus Comes, Chronicon, a. 441, [in:] Chronica minora, ed. Th. Mommsen, Berolini 1894 [= MGH.AA, 11.2]. Concerning further problems with the Isaurians, including Isaurian robbers in early Byzantium, see the recent article by: M.J. LeszKA, Jan Kyrtos - pogromca Izauryjczyków, [in:] W kregu antycznych politei. Księga Jubileuszowa ofiarowana profesorowi Janowi Ilukowi, ed. W. GajewsKi, I. Milewski, Gdańsk 2017, p. 204-211.
} 
For the Isaurian robbers, captives abducted for ransom constituted a considerable source of income, along with the loot itself. If there was nobody to ransom a given prisoner, or if the demanded sum was too high, they would end up at a slave market. Chiefly, the Isaurians tried to kidnap people from higher social classes or those enjoying universal respect, such as eremites. A substantial ransom could be hoped for in the case of their abduction. Exactly such a case is reported in Theodoret's Historia religiosa; it concerns Theodosius, a monk from northern Syria. It was the fear of kidnapping, among other factors (such as securing safety) that determined Theodosius's evacuation to the safe haven of Antioch ${ }^{32}$. During the very same raid, the Isaurians captured two bishops from Syria. Theodoret does not mention their names or provide any chronological clues that would allow us to establish the time of the event. As mentioned above, other sources report that Isaurian raiding parties reached the territories of Syria, Phoenicia and even Palestine during raids that occurred between $403 \mathrm{AD}$ and $408 \mathrm{AD}$. Therefore, the incident described by Theodoret may also be dated to the same period with a high dose of certainty. As for the two bishops, they were released after long negotiations, their bishoprics agreeing to pay 40,000 solidi - an exorbitant sum at the time ${ }^{33}$. Theodoret mentions Isaurians kidnapping people for ransom in other parts of his work as well ${ }^{34}$.

Nevertheless, the Isaurians were inhabitants of the Roman Empire. On the other hand, in late antiquity, the southern periphery of the state - Egypt - was subject to raids by borderland peoples, such as the Blemmyes ${ }^{35}$. Their pillaging expeditions reached Thebaid $^{36}$ and even Sinai ${ }^{37}$, escalating in the thirties and

\footnotetext{
${ }^{32}$ Theodoretus, Historia Religiosa, X, 6, p. 446.

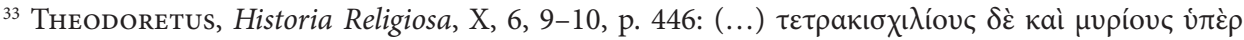

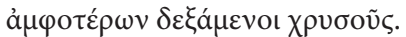

${ }^{34}$ Theodoretus, Historia Religiosa, XII, 6; XXI, 27. A possible sum of money for releasing captives is also disclosed by Procopius of Caesarea. According to his account, the Persian king Chosroes purportedly captured as many as 12,000 inhabitants when conquering the city of Sura. Subsequently, he offered Candidus, bishop of the nearby Sergiopolis, to ransom them for the staggering sum of 2,000 kentenaria of gold, cf. Procopius, Bellum Persicum, II, 5, 28, ed. J. Haury, G. Wirth, Leipzig 1963. Vide also: A. Cameron, Procopius and the Sixth Century, Berkeley-Los Angeles 1985, p. 163. Other sums reported by Procopius in his Persian War pertain not to ransom, but to tribute for lifting the siege of a city.

${ }^{35}$ Notitia Dignitatum, 31, 49, [in:] Notitia Dignitatum. Notitia urbis Constantinopolitanae. Latercula Provinciarum, ed. O. Seeck, Frankfurt am Main 1983, p. 65; Historia monachorum in Aegypto, 1, 2, ed. A.J. Festugière, Bruxelles 1971, p. 9-10. Cf. also: M. Weber, Blemyer, [in:] RAC, SupplementLieferung, Stuttgart 2002, p. 7-28.

${ }^{36}$ Palladius, Historia Lausiaca, 32, ed. C. Butler, vol. II, Cambridge 1904, p. 95, 2-5.

${ }^{37}$ V. Christides, Pre-islamic Arabs in byzantine illuminations, Mu 83, 1970, p. 176sqq; J. Desanges, Les raids des Blemmyes sous le règne de Valens en 373/74, MNe 10, 1972, p. 32-34. R. SolzBACHER, Mönche, Pilger und Sarazenen. Studien zum Frühchristentum auf der südlichen Sinaihalbinsel, Altenberge 1989, p. 212sqq, 234-242; T. Power, The Red Sea from Byzantium to the Caliphate. Ad 500-1000, Cairo 2012, p. 47 (fn. 5-6).
} 
forties of the $5^{\text {th }}$ century, as reported by Shenoute of Atripe. If his account is to be trusted, during one such raid the Blemmyes acted in a particularly cruel way. The population, left on their own (supposedly in the number of 20,000), took shelter in the Sohag monastery under the custody of Shenoute. The archimandrite guaranteed their protection and upkeep and ransomed 100 captives from the Blemmy$\mathrm{es}^{38}$. One of the victims of the Blemmyes' raid of $435 \mathrm{AD}$ was Nestorius, the bishop of Constantinople, who was an exile in Siwa Oasis at the time ${ }^{39}$. The Blemmyes continued their attacks in the later decades as well ${ }^{40}$.

The above study offers a detailed analysis of two reports (by Gerontius of Jerusalem and Theodoret of Cyrus, respectively) concerning various forms of brigandage in late antiquity. Although the phenomenon developed widely during the whole period of antiquity (and not only then), the crisis and progressive decline of Roman administration in the West could only lead to the increase of its scale and intensity. The sources analyzed - both of them hagiographic texts - reflect the atmosphere of the époque: an infirm (often helpless) state facing growing crime, the effects of migration, as well as pirate raids launched from neighboring barbarian lands. Despite a certain lack of precision, the accounts under discussion are valuable sources of knowledge. They depict everyday life in the provinces, reflecting "stories" left untold in "great history", allowing a reconstruction of the social and political history of the later Roman Empire.

\section{Bibliography}

\section{Sources}

Ammianus Marcellinus, Rerum gestarum libri, vol. I-II, ed. W. Seyfarth, Stuttgart 1996.

Evagrius, Historia ecclesiastica, ed. J. Bidez, L. Parmentier, Amsterdam 1964.

Gerontius, Vita Melaniae iunioris, ed. D. Gorce, Paris 1962 [= Sources chrétiennes, 90].

Gregorius Magnus, Epistulae, ed. D. Norberg, Turnhout 1982 [= Corpus christianorum, Series latina, 140].

Hieronymus, Chronicon, ed. R. Helm, Berlin 1956.

Hieronymus, Epistulae, ed. J.-P. Migne, Paris 1845, col. 235-1182 [= Patrologiae cursus completus, Series latina, 22].

Historia monachorum in Aegypto, ed. A.J. Festugière, Bruxelles 1971.

${ }^{38}$ Cf. J. LeIPOLDT, Berichte Schenutes über Einfälle der Nubier in Ägypten, ZÄSA 40, 1902, p. 126-140; R.T. Updegraff, A Study of the Blemmyes, Ann Arbor 1978, p. 107sqq.

${ }^{39}$ Evagrius, Historia ecclesiastica, I, 7, 13, ed. J. Bidez, L. Parmentier, Amsterdam 1964. Cf. also: F. HAAsE, Altchristliche Kirchengeschichte nach orientalischen Quellen, Leipzig 1925, p. 382; R.T. Updegraff, A Study..., p. 109-110; I. Milewski, Depozycje i zsyłki biskupów w Cesarstwie Wschodniorzymskim (lata 325-451), Gdańsk 2008, p. 365-366.

${ }^{40} \mathrm{M}$. Weber, Blemyer..., p. 21 sqq. 
Joannes Chrysostomus, Epistolae, ed. J.-P. Migne, Paris 1862, col. 529-791 [= Patrologiae cursus completus, Series graeca, 52].

JoAnnes Chrysostomus, Epistolae ad Olympiadem / Lettres d'exil a Olympias et a tous les fidèles, ed. A.-M. Malingrey, Paris 1964 [= Sources chrétiennes, 103].

Marcellinus comes, Chronicon, [in:] Chronica minora, ed. Th. Mommsen, Berolini 1894, p. 37-108 [= Monumenta Germaniae historica, Auctores antiquissimi, 11.2].

Notitia Dignitatum, [in:] Notitia Dignitatum. Notitia urbis Constantinopolitanae. Latercula Provinciarum, ed. O. SEeCK, Frankfurt am Main 1983, p. 1-102.

Palladius, Dialogue sur la vie de Jean Chrysostome, eds A.M. Malingrey, P. LeclercQ, Paris 1988 [= Sources chrétiennes, 341-342].

Palladius, Historia Lausiaca, ed. C. Butler, vol. II, Cambridge 1904.

Philostorgius, Historia Ecclesiastica, ed. J.-P. Migne, Paris 1864, col. 459-638 [= Patrologiae cursus completus, Series graeca, 65].

Procopius, Bellum Persicum, ed. J. Haury, G. Wirth, Leipzig 1963.

Socrates, Historia Ecclesiastica, ed. J.-P. Migne, Paris 1864, col. 28-842 [= Patrologiae cursus completus, Series graeca, 67].

Sozomenus, Historia Ecclesiatica, ed. J.-P. Migne, Paris 1864, col. 843-1630 [= Patrologiae cursus completus, Series graeca, 67].

Theodoretus, Historia Religiosa / Histoire des mones de Syrie, ed. P. Canivet, A. Leroy-MolingHEN, Paris 1977 [= Sources chrétiennes, 234].

Zosimos, Historia nova, ed. F. Paschoud, vol. I-III, Paris 1971-1986.

\section{Secondary Literature}

Cameron A., Procopius and the Sixth Century, Berkeley-Los Angeles 1985.

Christides V., Pre-islamic Arabs in byzantine illuminations, "Le Muséon" 83, 1970, p. 167-181.

Coon L.L., "Through the Eye of a Needle". Wealth and Poverty in the Lives of Helena, Paula, and Melania the Younger, [in:] EADEM, Sacred Fictions. Holy Women and Hagiography in Late Antiquity, Philadelphia 1997, p. 95-119.

Desanges J., Les raids des Blemmyes sous le règne de Valens en 373/74, "Meroitic Newsletter" 10, 1972, p. 32-34.

Feld K., Barbarische Bürger. Die Isaurier und das Römische Reich, Berlin-New York 2005.

Graus F., Die Gewalt bei den Anfängen des Feudalismus und die "Gefangenbefreiungen" der merowingischen Hagiographie, "Jahrbuch für Wirtschaftsgeschichte" 1, 1961, p. 61-156.

Grieser H., Der Loskauf Gefangener im spätantiken christlichen Italien, [in:] Gefangenenloskauf im Mittelmeerraum. Ein interreligiöser Vergleich. Akten der Tagung von 19. bis 21. September 2013 an der Universität Paderborn, Hildesheim 2015, p. 25-54.

HaAse F., Altchristliche Kirchengeschichte nach orientalischen Quellen, Leipzig 1925.

Hermann-Otto E., Der spätantike Bischof zwischen Politik und Kirche. Das exemplarische Wirken von Epiphanius von Pavia, "Römische Quartalschrift für christliche Altertumskunde und für Kirchengeschichte" 90, 1995, p. 198-214.

KLIngshirn W., Caesarius of Arles and the Ransoming of Captives in Sub-Roman Gaul, "Journal of Roman Studies" 75, 1985, p. 183-203. 
Leipoldt J., Berichte Schenutes über Einfälle der Nubier in Ägypten, "Zeitschrift der Ägyptischen Sprache und Altertumskunde" 40, 1902, p. 126-140.

LeszKa M.J., Jan Kyrtos - pogromca Izauryjczyków, [in:] W kręgu antycznych politei. Ksiegga Jubileuszowa ofiarowana profesorowi Janowi Ilukowi, ed. W. GaJewski, I. Milewski, Gdańsk 2017, p. 204-211.

Merкт A., Maximus I. von Turin. Die Verkündigung eines Bischofs der frühen Reichskirche im zeitgeschichtlichen, gesellschaftlichen und liturgischen Kontext, Leiden-New York-Köln 1997.

Milewski I., Depozycje i zsyłki biskupów w Cesarstwie Wschodniorzymskim (lata 325-451), Gdańsk 2008.

Power T., The Red Sea from Byzantium to the Caliphate. Ad 500-1000, Cairo 2012.

RApP C., Holy Bishops in Late Antiquity, Berkeley 2005.

Schumacher L., Sklaverei in der Antike. Alltag und Schicksal der Unfreien, München 2001.

Solzbacher R., Mönche, Pilger und Sarazenen. Studien zum Frühchristentum auf der südlichen Sinaihalbinsel, Altenberge 1989.

Souza De Ph., Piracy in the Graeco-Roman World, Cambridge 2002.

Tомаschitz K., Unpublizierte Inschriften Westkilikiens aus dem Nachlass Terence B. Mittfords, Wien 1998.

Updegrafr R.T., A Study of the Blemmyes, Ann Arbor 1978.

WARD Ph., The Aeolian Islands, New York 1974.

Weber M., Blemyer, [in:] Reallexikon für Antike und Christentum, ed. T. KLAUSER, Supplement-Lieferung, Stuttgart 2002, p. 7-28.

\begin{abstract}
The article analyzes certain early Byzantine hagiographic texts concerning various forms of brigandage (both maritime and land-based). Two such accounts are studied in detail, one by Gerontius of Jerusalem and another by Theodoret of Cyrus. The instances described unveil the weakness of Roman state structures at the borders of the state as well as in lands harassed by barbarian raids, including piracy. Despite certain flaws (mostly the lack of precision), the accounts under discussion constitute valuable and reliable sources of historical knowledge.
\end{abstract}

Keywords: late antiquity, early Byzantium, brigandage in antiquity, money.

Ireneusz Milewski

Uniwersytet Gdański

Wydział Historyczny

Instytut Historii

Zakład Historii Starożytnej

ul. Wita Stwosza 55

80-308 Gdańsk

Polska/Poland

hisim@univ.gda.pl 